\title{
Shared Sanctity: Some Notes on Ahl al-Bayt Shrines in the Early Ṭālibid Genealogies*
}

\author{
Teresa Bernheimer \\ University of Oxford
}

This article examines some of the earliest literary evidence for Ahl al-Bayt shrines, contained in the so-called Țâlibid genealogies. First written in the mid- to late-gth century, nearly contemporaneously with the development of the earliest shrines themselves, these sources were often written by (and perhaps mainly for) the Ahlal-Bayt themselves, providing a picture that the family itself sought to preserve and convey. According to these sources, by the end of the gth century there clearly were burial places of the Ahl al-Bayt, and especially of the 'Alid family, that were visited. Such sites were associated with a number of "Alids who were not Shi'ite imams, but "regular" members of the family; thus they were not places of pilgrimage for the Shi'a only, but sites of veneration that could be shared and even developed regardless of sectarian affiliation. The sites, moreover, became focal points for the Ahl al-Bayt, many of whom settled around them, and came to benefit from their waqf arrangements and the pilgrimage "traffic" around them. Over all, the paper argues that the appearance of-or increased attention to - the Ahl al-Bayt shrines from the gth century onwards had little to do with Shicism or Shicite patronage; instead, it may be seen as consistent with the wider development of the socio-religious rise of the Ahl al-Bayt: the development of "Alidism".

To this day, the ubiquity of mausolea and shrines in all parts of the Islamic world is striking to any traveller: from the Taj Mahal in Agra, to the grand structures in Bukhara and Samarqand, to the famous Mamluk and Ayyubid

* A first version of this article was presented at the 2007 MESA conference in Montreal, as part of the panel Sharing Sanctity: Veneration of the Family of the Prophet as Non-Sectarian Social Praxis. I would like to thank the chair, the late Professor Oleg Grabar, my co-organisor Stephennie Mulder, and the other contributors and members of the audience for valuable comments on the first draft. 
shrines in Jerusalem, Damascus and Cairo, to the many smaller places of worship elsewhere: in many ways, different kinds of funerary buildings have become a quintessentially Islamic sight over a vast geographic and cultural area. Yet, the relative scarcity of funerary buildings dating to the first three centuries of Islam has long puzzled scholars especially of Islamic art. Should we assume that funerary buildings of the first three centuries of Islam did not survive, or did they never exist? Where did the building types originate? ${ }^{1}$ In what ways did the disapproval of some Islamic scholars of the building over graves influence social praxis? ${ }^{2}$ How do we account for the relatively sudden appearance of shrines and tombs after the ninth century?

Some of the earliest surviving examples of Islamic funerary architecture are sites attributed to the Ahlal-Bayt, the family of the Prophet Muhammad, often equated with Shicism. In his famous 1966 article on "The earliest Islamic commemorative structures", Oleg Grabar suggests that Shicism and secular glorification were "the two factors which first caused the growth of mausoleums", and these two factors "remained throughout as the main source of memorial constructions". ${ }^{3}$ Indeed, the role of Shi ism and Shicite dynasties played in the development and formulation of Islamic funerary and commemorative architecture remains central to the discussion on the origins and early development of Islamic shrines. ${ }^{4}$ Amongst those arguing against placing too great an emphasis on the influence of Shicite dynasties is Christopher Taylor: "... it is doubtful", he says, "that the genesis of

1 For a summary discussion of the origins of the mausoleum in Islam, which excludes Iran as a possible place of origin, see Robert Hillenbrand, Islamic Architecture, pp. 253-330; for a list of the earliest Islamic funerary buildings, see Yūsuf Rāgib, "Les premiers monuments funéraires de l'Islam", Annales Islamologiques 9 (1970), pp. 21-36.

2 Recent scholarship suggests that the importance of the levelling of graves (taswiyat al-qubūr) and the disapproval of built tomb structures in Islam has been overstated in earlier scholarship. See for instance Thomas Leisten, Architektur für Tote (Berlin, 1998), pp. 10-12; idem, "Between Orthodoxy and Exegesis: Some Aspects of Attitudes in the Sharīa Toward Funerary Architecture, Muqarnas 7 (1990), pp. 12-22; and Leor Halevi, Muhammad's Grave. Death Rites and the Making of Islamic Society (New York, 2007), pp. 187-196.

3 Oleg Grabar, "The Earliest Islamic Commemorative Structures", Ars Orientalis VI (1966), p. 46.

4 See Christopher Taylor, "Reelvaluating the Shici Role in the Development of Monumental Islamic Funerary Architecture: The Case of Egypt", Muqarnas 9 (1992), pp. 1-10. 
monumental commemorative and funerary architecture in Egypt owes itself primarily to Shi'i inspiration." ${ }^{5}$ Taylor's research has focused mostly on medieval Egypt and Syria, where the rule and patronage of the Fātimid dynasty may well present a special case. Yet even here, the shrines to members of the Prophet's family can be shown to have had universal appeal. He suggests that one should understand the cult of Muslim saints as part of the larger and long-standing phenomenon of the veneration of the dead in the Middle East. Taylor emphasizes that the visitation of graves (ziyāra) is a central aspect of this continuing tradition. ${ }^{6}$

It is in this context that the shrines of the Ahl al-Bayt, and in particular the shrines of the 'Alids, Muhammad's descendants through his daughter Fāțima and his cousin 'Alī, need further attention. Two recent studies have looked at some of these shrines and examined their origin and relationship with Shi'ism: Whilst James Allan's work focuses on the art and architecture of the shrines of the Twelver Shicite Imāms in Iraq and Iran and emphasizes the Shi ite character of the sites, Stephennie Mulder examines the shrines of the 'Alids in medieval Syria and suggests that they often served as unique spaces of inter-sectarian exchange and devotion. ${ }^{7}$ This paper contributes to the discussion by evaluating some of the earliest literary evidence for Ahlal-Bayt shrines, contained in the so-called Țālibid genealogies. It argues that the appearance of and increased attention to 'Alid shrines from the ninth century onwards had little to do with Shicism or Shicite patronage, but may be seen as consistent with the wider development of the rise of

5 Taylor, "Reevaluating the Shi'i Role", p. 1. Grabar's arguments and their influence on later scholarship were eloquently summarized by Taylor. Taylor's point is developed in the work of Joseph Meri on the cult of saints in medieval Syria. He highlights the sacred aspects of shrines and pilgrimage among Muslims, Jews, and Christians, and stresses the sharing of a fundamental set of rituals around the veneration of saints; see Josef Meri, The Cult of Saints Among Muslims and Jews in Medieval Syria (Oxford, 2002), especially pp. 120-213, and 284; idem, "The Etiquette of Devotion in the Islamic Cult of Saints", in James Howard-Johnston and Paul Anthony Hayward (eds.), The Cult of Saints in Late Antiquity and the Early Middle Ages (Oxford, 1999), p. 265.

${ }^{6}$ Christopher Taylor, In the Vicinity of the Righteous: Ziyāra and the Veneration of Muslim Saints in late Medieval Egypt (Leiden, 1999); and Taylor, "Reevaluating the Shici Role", p. 8.

7 James Allan, The Art and Architecture of Twelver Shi ism: Iraq, Iran and the Indian Sub-Continent (Oxford, 2012), pp. 5-39; and Stephennie Mulder, The Shrines of the 'Alids in Medieval Syria: Sunnis, Shi' is, and the Architecture of Coexistence (Edinburgh, forthcoming). 
the descendants of the Prophet Muhammad as a social class, independent of sectarian affiliation. Contrary to the view of Ibn Taymiyya, who fiercely condemned the visitation of tombs and termed it a heretical innovation (bid'a) of the Shi'ite Buyids, the veneration of 'Alid saints was a Sunni cult in as much as it was a Shic ite one; ${ }^{8}$ indeed, there was little specifically Shicite about the reverence for the family of the Prophet. ${ }^{9}$ Rather than a sign for the spread of Shi' ism, the emergence and visitation of 'Alid shrines were an expression of what may best be termed "Alidism" - the non-sectarian reverence of the Prophet's descendants..$^{10}$

The Țālibid genealogies are of particular relevance as they began to be written in the mid- to late-ninth century, and are thus contemporaneous with a proliferation of shrines associated with the descendants of the Prophet Muhammad. Based mostly on locally collected registers, these works especially emphasize which lineages continued and which ones died out. Their primary intent was to delineate who did and who did not belong to the family of the Prophet, and was thus entitled to certain privileges; their purpose was to consolidate and legitimize the family's standing as a distinct and distinguished social group. ${ }^{11}$ Even though these sources are primarily interested in the discussion of genealogical questions, real or imagined, and do not provide extensive information on the shrines, they nonetheless offer some of the earliest references to burial places of

8 Ibn Taymiyya, Majmū' Fatāwā Shaykh al-Islām Aḥmad b. Taymiyya (Riyadh, 1991), vol. 27, pp. $15^{1}$ and 393; quoted in Meri, Cult of Saints, pp. 273-274; Meri, "Etiquette of Devotion", pp. 273-279.

9 Kazuo Morimoto has recently drawn attention to a highly interesting group of Sunni traditions on the Prophet's family. Recommending the good treatment of the 'Alids in a variety of ways, these "edifying stories" were transmitted across sectarian boundaries, and show that "at the level of the day-to-day practice of believers, there has been no significant difference between the behaviors that advocates of the special treatment of the sayyid/shariffs in either sect have promoted." See Kazuo Morimoto, "How to behave towards sayyids and sharīfs. A trans-sectarian tradition of dream accounts", in Kazuo Morimoto (ed.), Sayyids and Sharifs in Muslim Societies: The Living Link to the Prophet (London/New York, 2012), pp. 15-36 (at p. 17).

10 F. E. Peters recently used the term with the slightly different meaning of "simple loyalty to the house of 'Ali". He similarly juxtaposes the term 'Alidism with Shi'ism. See F. E. Peters, The Monotheists. Jews, Christians, and Muslims in Conflict and Competition (Princeton, 2005), p. 285.

11 See Teresa Bernheimer, The 'Alids: The First Family of Islam, 750-1200 (Edinburgh, forthcoming). 
members of the Prophet's family. They include references to sites associated with 'Alids who are not known to have played any significant religious or political role. As both material and literary evidence for Islamic shrines are scarce for the first three centuries of Islam, this early material is of much value. Moreover, similar to the increased interest and emergence of Ahl al-Bayt shrines from the ninth century onwards, the proliferation of this literature is itself reflective of the rise of the 'Alids as "the first family of Islam".

\section{'Alidism}

As I have described in more detail elsewhere, the emergence of the 'Alid family as a distinct and distinguished social group was intimately connected with the rise and decline of the 'Abbāsid caliphate.12 Until the 'Abbāsid Revolution of 750, the "family of the Prophet" had generally included all of the Banū Hāshim; the movement that brought the 'Abbāsids to power had called for "the chosen one from the family of Muhammad" (al-rida min āl Muhammad)", generally understood to be a Hāshimite. ${ }^{13}$ Of course, some of the movement's supporters, and certainly most of the 'Alids themselves, had expected the revolution to enthrone a closer relative of the Prophet than an 'Abbāsid-preferably an actual descendant of the Prophet, a Hasanid or Husaynid. ${ }^{14}$ When this was not the case, and a number 'Alid revolts in the years and decades after the Revolution were unsuccessful, the 'Alids began to delineate more precisely who was included in the

12 For a detailed discussion, see Bernheimer, The 'Alids (forthcoming).

13 See P. Crone, "On the Meaning of the 'Abbāsid call to al-Riḍā", in C. E. Bosworth (ed.), The Islamic World. Essays in Honor of Bernard Lewis (Princeton, 1989), pp. 95-111; On Hāshimite Shi'ism, see W. Madelung, "The Hāshimiyyāt of al-Kumayt and Hāshimī Shi'ism", Studia Islamica 70 (1989), pp. 5-26.

14 The first serious challenge to the 'Abbāsids came in 145/762-3 with the uprising of two Hasanid brothers, Muhammad al-Nafs al-Zakiyya and Ibrāhīm. The 'Abbāsid caliph al-Manșūr not only violently confronted the rebels but also persecuted and imprisoned a number of other 'Alids. The tenth-century litterateur al-Mas'ūdī (d. 346/956) writes of this event: "it caused a split between the descendants of 'Abbās b. 'Abd al-Muțțalib and the family of Abū Țālib; prior to this, their cause was one (wa kāna qabla dhālika amruhum wāḥid)"; see al-Mas'ūdì (d. 345/954 or 356), Murūj al-Dhahab (Beirut, 1966-1979), vol. IV, p. 22. For a list of 'Alid rebellions, see Teresa Bernheimer, A Social History of the 'Alid Family from the 8th to the nth century (unpublished Ph.D. Thesis, Oxford 2006), Appendix I: 'Alid Revolts. 
The Family of the Prophet Muhammad

(Banu Hashim)

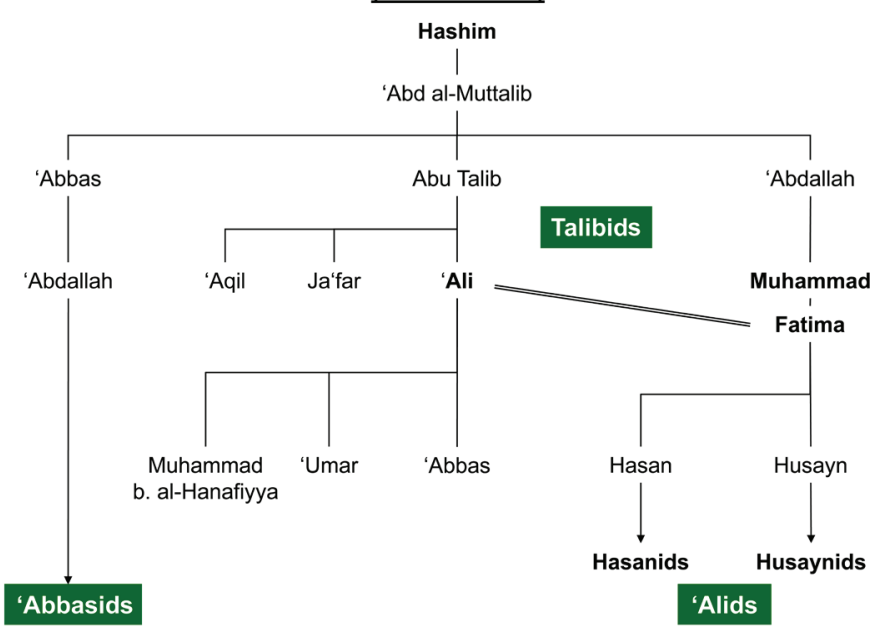

FAMILY TREE

Ahl al-Bayt. ${ }^{15}$ In very general terms, it was the distinctiveness from their 'Abbāsid cousins that was at the centre of this new self-definition'Abbāsids versus Țālibids. ${ }^{16}$

Moreover, whilst the rise of the 'Abbāsids to the caliphate marked the starting point for a clearer definition on part of the 'Alids of the true "family of the Prophet" (Ahl al-Bayt), the decline of "Abbāsid power from the ninth century onwards gave the 'Alids the opportunity to re-position themselves as the Prophet's legitimate heirs, genealogically, politically, as well as socially. Indeed, there were various ways in which the 'Alids' sense of a distinct and distinguished group took shape particularly in this period of "Abbāsid decline":17 many 'Alids left the Hijāz and settled especially in

15 Of course the definition of who belongs to the Ahlal-Bayt very much depended on the context, and on who did the defining; see for example M. Sharon, "People of the House", EQur'ān; for an excellent discussion of the related question of who qualifies as a sharîf, see C. van Arendonck/W. A. Graham, "sharif", EI2.

16 I focus on the 'Alids (rather than the wider kinship group of the Taalibids) to emphasize that at the centre of the emergence of this Islamic aristocracy were indeed the descendants of 'Alī, first and foremost his offspring from the marriage with Fāṭima, the Hasanids and Husaynids.

17 The most succinct discussion remains Hugh Kennedy, "The Decline and Fall of the First Muslim Empire”, Der Islam 81 (2009), pp. 3-30. 
the Islamic East to become one of the local elites of their cities; ${ }^{18}$ the 'Alids' marriage patterns became increasingly restrictive, so that 'Alids were to marry only other 'Alids; ${ }^{19}$ the office of the niqāba, the headship of the 'Alid family, was introduced and quickly spread all over the Islamic world;"20 and genealogical works of the Țâlibids, thus excluding explicitly the 'Abbāsid branch of the Banū Hāshim, began to be written in the middle of the ninth century. All of this points to the strengthening of an 'Alid identity, the currency of which was genealogy, not religion; indeed, whether Sunni or Shi ite, the important matter was to be, or to claim to be, a descendant of the Prophet.

It was also at this time that 'Alid shrines, if not first built, received new attention. One well-known example is the construction around the tomb of Fāțima, sister of 'Alī al-Riḍā (d. 203/818), in Qum, thought to be one of the earliest Muslim shrines in continuous use. ${ }^{21}$ Grabar tentatively dated it to the second half of the ninth century, emphasizing the difficulty of determining the precise structure of the tomb. ${ }^{22}$ But whatever the structures, both Sunnis and Shi ites were involved in developing the shrines of the Ahl al-Bayt: the most famous sites are perhaps the shrine at the supposed graves of 'Alī and Husayn at Najaf and Karbalā', re-commissioned

18 Teresa Bernheimer, "The Rise of Sayyids and Sādāt: The Case of the āl Zubāra in 9th-11th Century Nishapur," Studia Islamica 100-101 (2005), pp. 43-69.

19 Teresa Bernheimer, "Genealogy, Marriage, and the Drawing of Boundaries among the 'Alids (eight-twelfth centuries)", in Kazuo Morimoro (ed.), Sayyids and Sharifs in Muslim Societies: The Living Link to the Prophet (London/New York, 2012), pp. 191-233.

20 With the office of the niqāba, it was clear that the 'Alids had developed a self-consciousness as a group, and that they were considered to be distinct from the rest of society by others as well. For the spread of the niqāba, see Kazuo Morimoto, "A Preliminary Study on the Diffusion of the Niqābat al-Tălibìyin: Towards an Understanding of the Early Dispersal of Sayyids", in Hidemitsu Kuroki (ed.), The Influence of Human Mobility in Muslim Societies (London, 2003), pp. 3-42.

21 Richard Ettinghausen suggested that it may be the oldest surviving burial place in the Muslim world; see Richard Ettinghausen, "The Man-Made Setting", in Bernard Lewis (ed.), The World of Islam (London, 1992), pp. 57-88.

22 Grabar, "Commemorative Structures", p. 15. Regarding the historicity of the accounts of Fātima's death in Qum, see Takamitsu Shimamoto, "Some reflections on the origin of Qum: Myth and History", Orient 27 (1991), pp. 101-2, and Andreas Drechsler, Geschichte der Stadt Qum im Mittelalter (605-1305) (Berlin, 1999), pp. 129-131. 
by the Zaydī ruler Muhammad b. Zayd (d. 287/90o) ${ }^{23}$ after al-Mutawakkil's destruction half a century earlier; and the shrine of 'Alī al-Riḍā at Mashhad, which received patronage from the Sunni Sāmānids as well as the Ghaznavids and a number of Sunni rulers after them. ${ }^{24}$ Some of the less known Ahl al-Bayt shrines are first mentioned in the Taalibid genealogies; let us now turn to examine these sources in more detail.

\section{Ṭālibid Genealogies and 'Alid Shrines}

As Kazuo Morimoto has shown in various studies, the early Țālibid genealogies are an intriguing group of works: based on family (or local) registers, they were mostly written between the ninth and the eleventh century by genealogists (the nassāba) who were predominantly themselves 'Alids or Țālibids. ${ }^{25}$ They cover the genealogical information on the different branches of the family of the Prophet (usually in full for the first few generations, then only selectively), and give some (usually little) historical information on certain family members. The best known and most widely used of these works is the 'Umdat al-Ṭalib by the famous Imamì genealogist Ibn 'Inaba (d. 828/1424-5), ${ }^{26}$ but a number of earlier genealogies survive, among them the Sirr al-Silsila of Abū Nașr al-Bukhārī (d. mid-tenth century). ${ }^{27}$ Al-Bukhārì's Sirr al-Silsila is particularly interesting because of its early date, the author's (and redactors') wide and eclectic use of sources, and the relatively rich information on the state and location of each lineage. Al-Bukhārī

23 Ibn Isfandyār (fl. 1210-1216), Tārīkh-i Ṭabaristān (Tehran, 1941), vol. I, p. 95; Abū Ishạāq al-Șābi' (d. 384/994), al-Muntaza' min Kitāb al-Tājī (Baghdad, 1977), pp. 47-8; and Wilferd Madelung, "Abū Isḥāq al-Șābi' on the 'Alids of Ṭabaristān and Gīlān", JNES 26 (1967), p. 29, for further references.

24 Ibn al-Athīr, al-Kāmil fì 'l-Ta'rīkh (Beirut, 1965-67), vol. IX, p. 139; for a thorough examination of the history and patronage of the shrine at Mashhad, see May Farhat, Islamic Piety and Dynastic Legitimacy: The Case of the Shrine of 'Alı̀ b. Mūsā al-Rid̄ in Mashhad (1oth-17th century) (Iran) (unpublished dissertation Harvard University, 2002). For the shrines of the imāms in Iraq and Iran more generally, see Allan, The Art and Architecture of Twelver Shi ism, pp. 5-39.

25 For a most thorough study of the works see Kazuo Morimoto, "The Formation and Development of the Science of Tâlibid Genealogies in the 1oth and 11th century Middle East", Oriente Moderno 18, n.s. (1999), pp. 541-570.

26 B. Scarcia Amoretti, "Ibn 'Inaba", EI2.

27 Ibn 'Inaba, 'Umdat al-Ṭālib fi Ansāb Āl Abì Ṭālib (Najaf, 1961), new edition Mahdī al-Rajā'ì (Qum, 2004). 
is frequently quoted by later genealogists, such as Ibn Inaba, and thought to be very reliable. As regards the information on shrines, his knowledge (or interest) is not as detailed as one would wish—clearly al-Bukhārī was a genealogist, not an architectural historian. Nonetheless, some relevant information regarding the existence of known burial sites, the increasing importance of the shrines for the 'Alids and the wider Muslim community, and the vocabulary used to describe them can be gleaned from al-Bukhārì's Sirr al-Silsila and some of the later genealogies. Let us deal first with the question of vocabulary.

Thomas Leisten points out that none of the surviving inscriptions on mausolea or shrines before the 7 th $/ 13^{\text {th }}$ century use the word qabr. He moreover emphasizes that the terminology employed to distinguish between different types of early funerary architecture was far from clearly defined also in the literary material—qubba, turba, mashhad, or more rarely masjid and $q a b r$ were used relatively interchangeably. ${ }^{28}$ The geographer al-Muqaddasi in the Ahsan al-Taqāsim, for instance, speaks of the graves ( $q a b r$ ) of 'Alì and Husayn in Iraq, at a time when there were monumental structures in place, some of which al-Muqaddasi himself describes. ${ }^{29}$

The evidence from al-Bukhārī's Sirr confirms a certain fluidity regarding terminology. He uses the words qabr (grave) and mashhad (shrine or tomb, usually for a martyr/saint) when mentioning the places where 'Alids were buried, ${ }^{30}$ and it is certainly questionable whether the use of the word qabr as opposed to mashhad implied that there was no noteworthy architectural structure extant. In fact, there certainly were structures in some of the places al-Bukhārī refers to as qabr. For instance, he speaks of the qabr of Muḥammad al-Jawād in the Maqābir Quraysh in Baghdad — as we know from other authors, by the early tenth century this shrine had seen various kinds of building activity. ${ }^{31}$

Nonetheless, there appears to be a certain difference between the terms. Al-Bukhārī uses mashhad three times to describe the burial place of an 'Alid: he mentions a mashhad in Amul, of one Muhammad b. Ja far b. Hārūn (b. Isḥāq b. al-Ḥasan b. Zayd b. al-Ḥasan b. 'Alī), who was killed sometime

\footnotetext{
28 Leisten, Architektur für Tote, pp. 67-70; Meri, The Cult of Saints, pp. 262-272.

29 Al-Muqaddasī, Ahsan al-Taqāsìm (Leiden, 1906), p. 130.

30 Al-Bukhārī, Sirr al-Silsila, pp. 23 and 55 (Balājird—should read Talājird?); p. 38 (Baghdād, Maqābir Quraysh); p. 89 (Karbalā'); p. 37 (Marw); p. 36 (Nīshāpūr, Maqābir al-Hīra); pp. 46-47 (Baghdād), p. 51 (Miṣr, lāyu'arrifu qabruhu).

31 See for instance Ibn Isfandyār, Tārīkh-i Țabaristān, vol. I, p. 95.
} 
in the late 2nd/8th century by Rāfic b. al-Layth, "and his tomb is well-known (mashhaduhu zāhir), may it be blessed and its visitation". ${ }^{32}$ The two other instances of the term mashhad are the tomb of one al-Husayn b. 'Abdallāh, who died in Rayy in 319/930 (mashhaduhu zähir yuzäru), ${ }^{33}$ and the tomb of the Hasanid 'Alī b. 'Abd al-Raḥmān, who was killed in Vāramīn in the Jibāl in the reign of the caliph al-Mahdī (r. $775-785) \cdot{ }^{34}$ In all three cases, he says that the mashhad is well-known (zähir) and mentions the term in connection with visitation (ziyāra). There is no mention of ziyāra when he uses the term qabr, and only once does he say that a qabris well-known. ${ }^{35}$ Admittedly, the sample is rather small, and in the absence of further evidence one may only tentatively suggest that the vocabulary choice does indicate some sort of distinction.

What is clear, however, is that all three 'Alids buried in a mashhad are not known to have been of particular importance to the Shi'a. They are not known to have played any significant historical role, nor do they appear in the early Shicite visitation guides. ${ }^{36}$ These three tombs, and perhaps also the sites described as qabr, are thus some of the first recorded examples of shrines to venerate "regular" members of the Ahl al-Bayt (i.e. not shrines

32 Al-Bukhārī, Sirr al-Silsila, p. 26. For the lineage of the 'Alid, see the early genealogy of Yaḥyā b. al-Ḥasan al-'Aqīqī (d. 277/891), Kitāb al-Mu'aqqibìn min Wuld al-Imām Amìr al-Mu'minin (Qum, 2001), p. 74, or Shaykh al-Sharaf al-'Ubaydalī (d. 435/1043), Tahdhīb al-Ansāb wa-Nihāyat al-A'qāb (Qum, 1413/1992-93), p. 145. The uprising of al-Rāfi b. Layth in the year 190/805 is given in al-Ṭabarī, Ta'rīkh al-Rusulwa-'l-Mulūk (Leiden, 1879-1901), vol. III, pp. 707-709.

33 Al-Bukhārī, Sirr al-Silsila, p. 80; he is al-Husayn b. 'Abdallāh b. 'Abbās b. 'Abdallāh b. al-Hasan b. 'Alī b. 'Alī [b. al-Ḥusayn b. 'Alī].

34 Al-Bukhārī, Sirr al-Silsila, p. 22.

35 Al-Bukhārī, Sirr al-Silsila, p. 47 (the grave of al-Husayn b. 'Alī b. Muhammad b. Ja'far in Baghdad, who died there is the reign of al-Mu'tamid, r. 870-892).

36 One of the earliest extant visitation guides is Qūlawayh al-Qummī (d. 368/978 or 369/979), Kāmil al-Ziyārāt (Beirut, 1418/1997); see Meri, "ziyāra”, EI2. Works such as the Kāmil al-Ziyārāt show that, at least in the early period, "official" Shi'ite pilgrimage was associated especially with the imāms of the Imāmiyya, not the family of the Prophet in general. In comparison with the later Sunni cemetery guides, such as al-Harawī's (d. 611/1214) Kitāb al-Ishārāt, the Shicite works mainly contain litanies and traditions to be said at the sites. As Marco Schöller says, "we learn nothing of the actual location and shape of the shrines dealt with, and epitaphs are not quoted or alluded to. For the study of Islamic funerary epigraphy they [the Shi'i works] are therefore without any serious value"; see Werner Diem and Marco Schöller, The Living and the Dead in Islam: Studies in Arabic Epitaphs (Wiesbaden, 2004), vol. II, p. 298. 
to the Shicite imāms), which came to be so ubiquitous all over the Islamic world.

Many of these sites had a complex and multifaceted history: as al-Bukhārī and other genealogists say, patrons of varying affiliations structures tried to associate themselves with supposed burial sites of the Prophet's family, and at times commissioned structures around them. One example is the grave of Muhammad al-Dībāj in Jurjān: when one of the Zaydī rulers of Ṭabaristān, Muhammad b. Zayd b. Ismāîl, died on campaign in Jurjān in $287 / 900$, his headless torso (badan) was buried in the grave (qabr) of Muhammad al-Dībāj, another 'Alid rebel who had died there a century earlier. ${ }^{37}$ According to the local historian al-Qummì (fl. 378/988), a proper structure (turba) was erected only on the orders of the Būyid wazir al-Ṣāhib b. 'Abbād (d. 381/991) in 374/984. ${ }^{38}$

Another intriguing example of diverse patronage is the burial place of the Hasanid 'Abd al-Aẓim b. 'Abdallāh in Rayy, a well-known pilgrimage site still today. According to al-Bukhārī, 'Abd al-Azịim was buried in the masjid al-shajara, the only 'Alid he mentions to have been buried in a mosque. ${ }^{39}$ Ibn Qūlawayh al-Qummī (d. 368/978) includes the shrine in his Kämil al-Ziyārāt, one of the earliest pilgrimage guides for the Shi'a, which suggests that the tomb of 'Abd al-Azīm was already of some importance by the tenth century. This inclusion is indeed noteworthy, as together with the shrine of Fāțima bt. Mūsā in Qum, this is the only shrine of an 'Alid — who was not an imām-mentioned in the book. ${ }^{40}$ Still, the shrine was an important site not just for the Shi'a: as the twelfth-century scholar al-Qazwini reports, the Saljūq vizier Majd al-Mulk As'ad b. Muhammad b. Mūsā (d. 492/1099) ordered the construction of a mausoleum for 'Abd al-'Azịm.

37 Al-Bukhārī, Sirr al-Silsila, p. 27. His head was sent to the Sāmānid amīr in Bukhārā. For the tomb of Muhammad b. Jacfar al-Dībāj, a son of Jacfar al-Ṣādiq, known as qabr al-dā $\tilde{\imath}$, see al-Sahmī (d. 427/1035), Ta'rīkh Jurjān (Beirut, 1981), p. 36o, no. 620; also p. 248, no. 388; Ibn Funduq, Lubāb, p. 254. For al-Dībāj's revolt in Mecca and Medina in 20o/815, see al-Ṭabarī, Ta'rīkh, vol. III, pp. 989-995, and other references in Bernheimer, Social History, Appendix I: 'Alid Revolts, p. 174.

38 Al-Qummī, Tārīkh-i Qum (Tehran, 1982), pp. 223-224; Leisten, Architektur für Tote, p. 33 .

39 Al-Bukhārī, Sirr al-Silsila, p. 24; al-'Umarī (d. 450/1058), al-Majdī fì Ansāb al-Ṭālibiyyìn, (Qum, 1409), p. 219 (qabr); Fakhr al-Dīn al-Rāzī (d. 606/1209), alShajara al-mubāraka fì Ansāb al-Ṭālibiyya (Qum, 1410), p. 78 (mashhaduhu bihā [Rayy] ma'rüfwa-mashhür).

40 See Ibn Qūlawayh al-Qummī, Kāmil al-Ziyārāt (Beirut, 1418/1997), pp. 536537; Meri, The Cult of Saints, pp. 157-161; and J. Meri, "ziyāra”, EI2. 
Whatever the political context may have been, this was an important gesture of Sunni patronage, again showing the potentially inter-sectarian nature of such shrines. ${ }^{41}$

The third point emphasized in the genealogies is the fact that the areas around the shrines became focal points for members of the family of the Prophet. The role played by the 'Alids themselves in this development has been discussed in some detail by May Farhat, in her work on the shrine of 'Alī al-Ridā at Mashhad. She suggests that "the main impulse for the survival of the shrine was linked to a class of sayyids, descendants of the Prophet, who assumed the shrine's charismatic tradition, and appealed to a wide constituency, unfettered by ethnic and sectarian divisions". ${ }^{42}$

A similar situation is to be envisaged at a number of other places as well. The area around the shrines of the Twelver imāms in Baghdad, for instance, seem to have been so populated by 'Alids that they required their own naqīb (syndic or registrar): the early eleventh-century genealogist Shaykh al-Sharaf al-'Ubaydalī (d. 435/1043) has some references to the "Maqābir Quraysh" in Baghdad as a place where certain lineages had settled, and even held the niqāba. ${ }^{43}$ For the city of Qum, the site of another major shrine complex, the local historian al-Qummì records a book of monthly wages (kitāb-i mushāhara) in 371/981, from which the 'Alids were entitled to a pension (waziffa) of 30 mann of bread and 10 silver dirhams. ${ }^{44}$

Much economic activity took place at certain shrines, and towns and cities grew around them. Ibn Isfanyār, for instance, mentions the building of houses and shops in Sāmarrā, the site of the 'Askariyya shrine, on the order of 'Aḍud al-Dawla: the Būyid is said to have "surrounded these holy places

41 'Abd al-Jalīl b. Abū al-Hasan al-Qazwīnī (fl. 1189), Kitāb al-Naqḍ (Tehran, 1371/1952), p. 220; W. Barthold, An Historical Geography of Iran (Princeton, 1984), p. 127; Sheila Blair, The Monumental Inscriptions from Early Islamic Iran and Transoxania (Leiden, 1992), p. 185; Leisten, Architektur für Tote, pp. 240-241.

42 Farhat, Islamic Piety, p. iii, and Introduction, p. 1.

43 Al-'Ubaydalī (d. 435/1043), Tahdhībal-Ansāb;pp.98 (naqūb), 140, 206 (Maqābir Quraysh as a place where 'Alids lived); Ibn Țabāțabā, al-Muntaqila al-Ṭālibiyya, note p. 58. For a similar use of the mashhad of al-Ridiā, see al-Marwazī, al-Fakhrī, pp. 20, 22, 80. Eventually this became of course the actual name of the city.

44 Al-Qummī, Tärīkh-i Qum, p. 220; see Ann Lambton, "An Account of the Tärīkhi Qum", BSOAS 12 (1948), p. 596. For an excellent discussion of the history of the shrine, see Hossein Modarressi Țabāțabā'ī, Turbat-i pākān: āthāàr va bināhāa-yi qadìm-i maḥdüdah-i kunūnì-i dār al-mu'mininn-i Qum, 2 vols. (Qum, 1976). 
with houses and bazaars [...]". ${ }^{45}$ Associated with the shrine at Karbalā' is a story told by Ibn al-Jawzī: When the Būyid vizier al-Dabbī died in 398/1007, he had wanted to be buried in the mashhad complex; with the help of one Hanafī shaykh Abū Bakr al-Khwārazmī, his son offered the naqīb of the 'Alids, who was in charge of such matters, 500 Maghribì dinārs for a turba in the complex. ${ }^{46}$ The naqib allegedly declined the payment graciously, but agreed that the vizier could be buried in the mashhad complex and even escorted the coffin personally to the grave site. Even if formally declined in this case, money was clearly to be made around the shrines. So much so, in fact, that another genealogist, Ibn Funduq al-Bayhaqi urged the naqib to ensure that the poor members of the family (sādāt) find employment and work, "so that there is no need for them to go begging around our mosques $[\ldots] " .47$

\section{Conclusion}

Whilst the recording of burial sites was not a priority for the authors of Țâlibid genealogies, these sources nonetheless provide some new and exciting information on the development of Islamic funerary sites, particularly on 'Alid shrines. The examination of al-Bukhārī's Sirr al-Silsila, one of the earliest extant genealogies, shows that by the end of the ninth century there clearly were burial places of the 'Alid family that were visited. Many of the "Alids mentioned were not Shi ite imāms, but "regular" members of the family. The work, thus, gives some of the earliest references to the type of places that came to be venerated all over the Islamic world: shrines to local saints, who more often than not were outfitted with a Prophetic genealogy.

Moreover, the vocabulary to describe the burial sites of 'Alids was fluid, though not entirely interchangeable. Though this needs to be further investigated, the use of the simple qabr (grave) did not necessarily mean that there was no structure in place, whilst the term mashhad may indicate

45 E. G. Brown, An Abridged Translation of the History of Țabaristān (Leiden and London, 1905), p. 158. James Allan also gives the example of Mazar-e Sharif, which received patronage for the shrine as well as a bazaar with shops and a bath-house under the Timurids. See Allan, The Art and Architecture of Twelver Shi ism, p. 38.

46 Ibn al-Jawzī, Muntazam (Hyderabad, 1357-1359), vol. VII, p. 249; cited in Terry Allen, "The Tombs of the 'Abbāsid Caliphs in Baghdād", BSOAS 46 (1983), p. 425.

47 Ibn Funduq, Lubāb, p. 722. 
some sort of pilgrimage activity. The sites, moreover, were by no means places of pilgrimage for the Shi'a only, but places of veneration for members of the family of the Prophet that could be shared, at least at times, regardless of religious affiliation, and they were frequently developed by both Sunni and Shicite patrons. Finally, the shrines became major focal points for the descendants of the Prophet, many of whom settled in the areas around them, and benefited from and contributed to the economic activity associated with the sites.

It must be emphasized again, however, that the information in the Tâalibid genealogies regarding shrines and funerary sites is by no means exhaustive. One example is the mausoleum of the Zaydī 'Alid Hasan b. Zayd at Amul. According to Ibn Isfandyār, al-Hasan b. Zayd ordered the building of the monument before his own death in 270/884 to deceive his enemies. Al-Bukhārī and the later genealogists do not mention a tomb or any building activity, even though they preserve lengthy accounts on Hasan b. Zayd, including the circumstances of his death. ${ }^{48}$

Thus, one puzzling question is why the existence of tombs and shrines is so rarely discussed, in the genealogies as well as in other types of Islamic historiography. Indeed, there are other, perhaps more obvious works where such information is similarly lacking. Al-Ișfahānī's Maqātil al-Ṭālibiyyīn comes to mind, a work that recounts a long list of members of the family of the Prophet who were slain. Save two references on the destruction of the sites in Iraq by al-Mutawakkil and the tomb of Mūsā al-Kāzim in Baghdad, al-Iṣfahānī hardly mentions a grave. ${ }^{49}$ This is curious, especially in view of the great amount of information given about the places of death, or funerals, in the Maqātil as well as many of the other early histories: we are frequently told who prayed over a body or who lead the funerary procession, but rarely is there any mention of the grave, or any funerary construction. ${ }^{50}$

Not all eventual shrines, of course, were set among designated grave sites. Leisten has drawn attention to the common practice of house burials, of which little has thus far been written. Some of the well-known 'Alids of

48 Ibn Isfandyār, Tārīkh-e Țabaristān, p. 27; Leisten, Architektur für Tote, p. 102.

49 See al-Ișfahānī, Maqātil al-Ṭălibiyyìn, pp. 597-599, for the destruction of the gave of al-Husayn at Karbalā'; p. 505, for the funeral and grave (qabr) of Mūsā al-Kāzim in the Maqābir Quraysh in Baghdad, where one gets the sense that there was no great structure there (he describes the location of the grave in relation to another grave, of one 'Īsā b. 'Abdallāh al-Nawfalī).

50 See Halevi, Muhammad's Grave, for references on funerary processions and rites. 
the Būyid period were buried at home (sometimes before being transferred to a shrine or cemetery later on):51 the 'Askariyya complex at Sāmarrā, for instance, is said to have been the site of a house burial which eventually became a shrine. ${ }^{52}$ Yet, whatever its original site or structure, and whether or not recorded in the literature, the burial places of many member of the Ahl al-Bayt did come to matter, as their special blessings (barakāt) were thought to be transmitted to those visiting heir tombs and shrines; on account of their blood relationship to the Prophet, these 'Alids could act as intercessors, even beyond their lifetime. ${ }^{53}$

51 See for example Ibn al-Jawzī, Muntazam, vol. VII, p. 247 (Abū Aḥmad al-Ḥusayn b. Mūsā al-Mūsawī, naqīb in Baghdad 394/1003-4), Leisten, Architektur für Tote, p. 122; Ibn al-Jawzī, Muntazam, vol. VII, p. 283 (Muḥammad b. al-Ḥusayn al-Sharīf al-Raḍī, naqīb, died in 406/1014), Leisten, Architektur für Tote, p. 123; Ibn al-Jawzī, Muntaz̧am, vol. VIII, p. 126 ('Alī b. al-Ḥusayn Sharīf al-Murtaḍā, naqīb, died in 436/1044-5), Leisten, Architektur für Tote, p. 126; Ibn al-Jawzī, Muntazam, vol. X, p. 247 (Abū 'Abdallāh Aḥmad b. 'Alī al-Ḥusaynī, naqūb, died in 569/1173), Leisten, Architektur für Tote, p. 137.

52 Al-Ya'qūbī, Ta'rīkh (Leiden, 1883), p. 615; Leisten, Architektur für Tote, p. 253. One report by al-Bukhārī suggests that there were places where one did not want to be buried, and that were rather unacceptable: during the rule of the 'Alid Ḥasan b. Zayd (d. 270/884) in Ṭabaristān, another 'Alid called Ibn Khāla al-Ḥasan al-'Aqīqī was governor of Sārìya for the 'Abbasids (labasa al-sawād wa-khataba al-Khurāsāniyya). Al-Hasan b. Zayd eventually captured him and killed him, and buried him in the cemetery of the Jews in Sārīya ( fì maqābir al-Yahūd bi-Sārīya) clearly to be understood as a punishment; see al-Bukhārī, Sirr al-Silsila, p. 27. The 'Alid was Ibn Khāla al-Ḥasan b. Muḥammad b. Ja'far b. 'Abdallāh b. al-Ḥusayn al-Ṣaghīr b. 'Alī b. al-Husayn al-'Aqīqī.

53 For some examples, see for instance, Valerie J. Hoffmann, "Shafā'a", EQur'ān. 